\title{
Consolidated Reporting Technology: Objectives and Means of Achieving
}

\author{
N.D. Brovkina, E.V. Negashev, R.M. Magomedov
}

\begin{abstract}
Automated consolidation of financial statements may increase reporting transparency. This paper deals with the IFRS-based automation processes aimed to improve the financial reporting transparency, which cannot be positively achieved through an entity's accounting practices based on the national accounting standards

Index Terms: automation, consolidated financial statement, separate financial statement, transparency, group structure
\end{abstract}

\section{INTRODUCTION}

A consolidated financial statement is a combined financial statement of two or more entities that have any sort of legal or business affiliation with each other. A consolidated financial statement reports the financial results and financial standing of the entire group, rather than individual companies and divisions. What this means is that consolidated profit is a total of financial results of all the members of the group, where a negative financial result of one entity can be covered by a profit of another entity. This should be taken into account when analyzing consolidated financial statements $[1,3,7,19,20]$.The objective of a consolidated financial statement is to provide the shareholders, investors and state authorities with a complete picture of the assets, financial situation, and consolidated financial results of the group as a single economic entity.

Consolidated financial statements combine like items of separate financial statements, subject to adjustments for the effects of intragroup transactions.Consolidated financial statements normally include a consolidated balance sheet, a consolidated statement of comprehensive income, a consolidated statement of changes in equity, and a consolidated cashflow statement.

\section{METHODS AND MATERIALS}

\section{A. GENERAL DESCRIPTION}

Prior to financial consolidation, all mutual settlements and other financial arrangements between the parent and its subsidiaries and between the subsidiaries must be duly reconciliated and settled.The consolidation procedure includes two stages: first,

Revised Manuscript Received on November 15, 2019

N.D. Brovkina, Ph.D. (Economics), Associate Professor, Department of Accounting, Analysis, and Audit of the Financial University under the Government of the Russian Federation, Moscow, Russia,

E.V. Negashev, Ph.D. (Economics), Associate Professor, Department of Accounting, Analysis, and Audit of the Financial University under the Government of the Russian Federation, Moscow, Russia

R.M. Magomedov, Ph.D., associate professor of the Department of Data Analysis, Decision-making and Financial Technology of the Financial University under the Government of the Russian Federation, Moscow, Russia like items of separate financial statements are combined, then any intragroup liabilities, assets, financial results are eliminated to avoid double accounting $[2,8]$.

Table 1 summarizes the items to be excluded from the group's consolidated financial statement $[15,18]$.

Table 1 Items to be excluded from the group's consolidated financial statement

\begin{tabular}{|l|l|}
\hline Items to be excluded from & Items to be excluded from the
\end{tabular} the consolidated balance consolidated statement of \begin{tabular}{l|l} 
sheet & comprehensive income
\end{tabular}

\begin{tabular}{l|l|}
\hline 1. Intragroup investments & 1. Intragroup trading revenue
\end{tabular}

2. Intragroup equity holdings 2 . Intragroup trading cost of

3. Intragroup liabilities sales

\begin{tabular}{l|l} 
4. Intragroup loans & 3. Any other proceeds or
\end{tabular}

5. Intragroup dividends expenses resulting from

6. Profits or losses resulting intragroup transactions

from intragroup transactions 4 . Intragroup dividends

All separate financial statements to be included in the consolidate financial statement shall have the same reporting dates. If the group companies have different fiscal year-ends, a subsidiary shall prepare an interim financial statement as of the parent's fiscal year-end.

The interrelation between affiliates results in double accounting. Therefore, an entity's financial statement must contain related party disclosures if the entity:

- $\quad$ is under control or significant influence of another entity or person;

- has control or significant influence over another entity;

- $\quad$ is under common control or significant influence with another entity.

Related party disclosures must report the nature of the relationship between the reporting entity and its related parties, as well as any related party transactions taking place in the reporting period.

The list of related parties to be disclosed in the entity's annual financial statement is determined by the reporting entity. However, for a consolidated financial statement, such list is established by the parent.

If there have been any related party transactions in the reporting period, either of such related parties must include the following disclosures in its financial statement at the very least:

- Nature of the related party relationship (control or significant influence);

- Transaction types;

- Total amounts of transactions of each type (in absolute or relative terms);

- Outstanding balances under pending transactions as of the 


\section{Consolidated Reporting Technology: Objectives and Means of Achieving}

end of the reporting period;

- Terms and conditions of settlements under the transactions and the method of payment;

- Provisions for doubtful debts as of the end of the reporting period;

- Receivables with an expired statute of limitations written off and other uncollectible debts written off, including those against the provision for doubtful debts $[4,9,10]$.

Related party disclosures must be included in the financial statement as a separate note thereto.

Consolidated financial statements are of importance to the management and investors since they are more interested in understanding the financial position and financial results of the group as a whole, rather than those of individual companies.

\section{B. ALGORITHM}

According to the International Financial Reporting Standards (IFRS) or the US Generally Accepted Accounting Principles (GAAP), for the purposes of consolidation of financial statements, special attention should be paid to whether effective control is exercised over a subsidiary.

The most common financial consolidation methods are reported in Table $2[5,14]$.

Table 2Financial consolidation methods

\begin{tabular}{|l|l|l|l|}
\hline Investor share & Parties & $\begin{array}{l}\text { Consolidation } \\
\text { method }\end{array}$ & Standard \\
\hline Up to 20\% & $\begin{array}{l}\text { Investor and } \\
\text { investee }\end{array}$ & Cost method & IFRS 7, 9 \\
\hline $20 \%$ to 50\% & $\begin{array}{l}\text { Investor and } \\
\text { associated } \\
\text { company }\end{array}$ & $\begin{array}{l}\text { Proportionate } \\
\text { method }\end{array}$ & IAS 28 \\
\hline 50\% and up & $\begin{array}{l}\text { Parent and } \\
\text { subsidiary }\end{array}$ & $\begin{array}{l}\text { Purchase } \\
\text { method }\end{array}$ & IFRS 3 \\
IAS 27
\end{tabular}

For the purposes of financial consolidation, uniform accounting rules (policies) must be implemented in all of the group companies, which is easily achieved if there is effective control over the subsidiaries.

In addition to consolidated financial results, a parent must provide segment disclosures.

Segment reporting is the reporting of assets and financial results by operating segments. Segment disclosures in a consolidated financial statement is a sort of "step back". On the one hand, separate financial statements are combined into a consolidated financial statement. On the other hand, IFRS Standards require entities to disclose information on the reportable segments, if the revenue in such segments constitutes $10 \%$ or more of the group's combined revenue. Thus, the information is broken down by businesses and operating segments. Such segments may or may not be represented by the group companies. Here, the economic substance overrides the legal form since entities involved in such business may be represented by either a division of a company, a whole company or several companies within the group.

\section{RESULTS AND DISCUSSION}

Advantages and Challenges of Automated Consolidation Corporate evolution involves automation of its business processes, including financial and management accounting. Automation provides a number of advantages, including improved accuracy of accounts and, therefore, improved accuracy of financial statements, quick preparation of financial statements, reduced risk of human errors, staff reduction. At the same time, there are certain challenges caused by higher requirements for the staff qualifications in view of the reduced number of employees. The number of routine operations decreases, whereas the number of operations requiring special qualifications increases. On the other side, automation of accounting and reporting operations allow for more complex holding structures, improves accounting processes for separate financial statements and consolidated financial statements (Fig. 1).

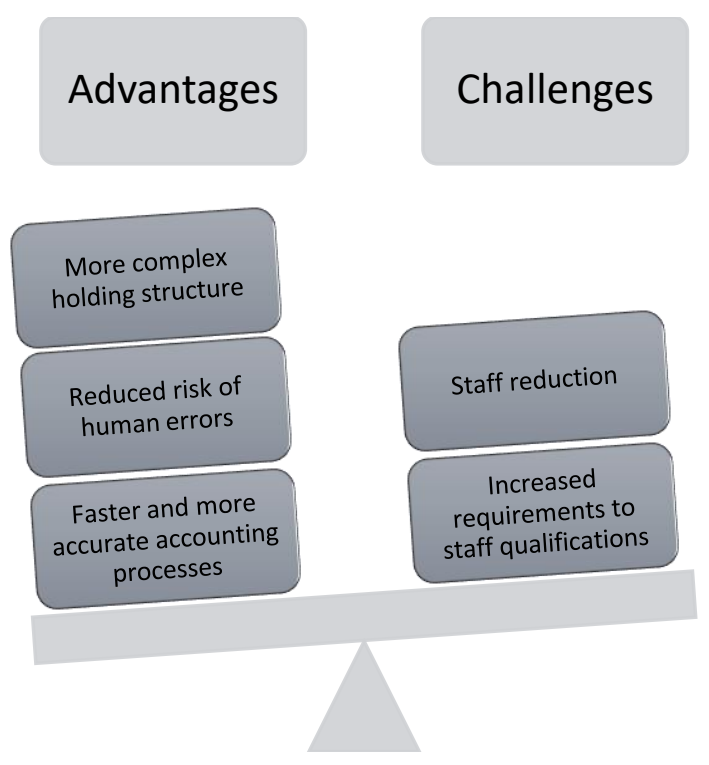

Fig. 1. Pros and cons of reporting automation Financial consolidation is associated with a number of challenges attributable to the internal and external factors and issues. Factors affecting the consolidation process are shown in Fig. 2.

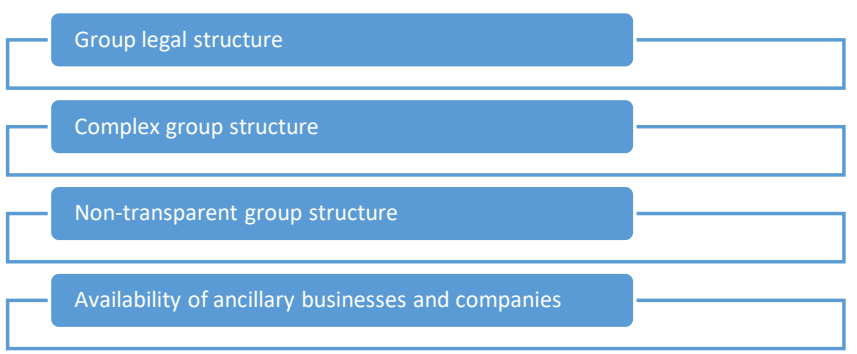

Fig. 2. Factors affecting the consolidation process

From the point of view of its legal structure, a group may consist of a great number of legal entities. A group may have a complex structure, i.e. have many subsidiaries and cross holdings, associated companies, joint ventures, lower-tier subsidiaries, etc. From the legal point of view, a group structure may be considered non-transparent if the relation is determined not so much by the equity share as by the

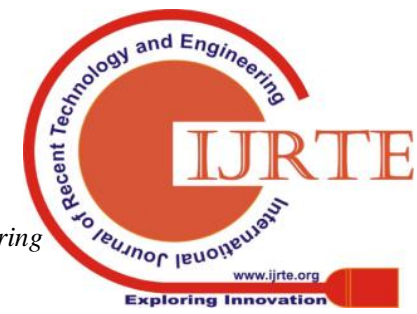


availability of control or influence. Ancillary businesses and companies within a group also make automation more labor-consuming, and, therefore, more expensive, since the cost of obtaining information about such companies has to be comparable with the usefulness of such information. All of the above increase the amount of effort required to automate the accounting and reporting processes.

There are also some challenges related to separate financial reporting within the group (Fig. 3).
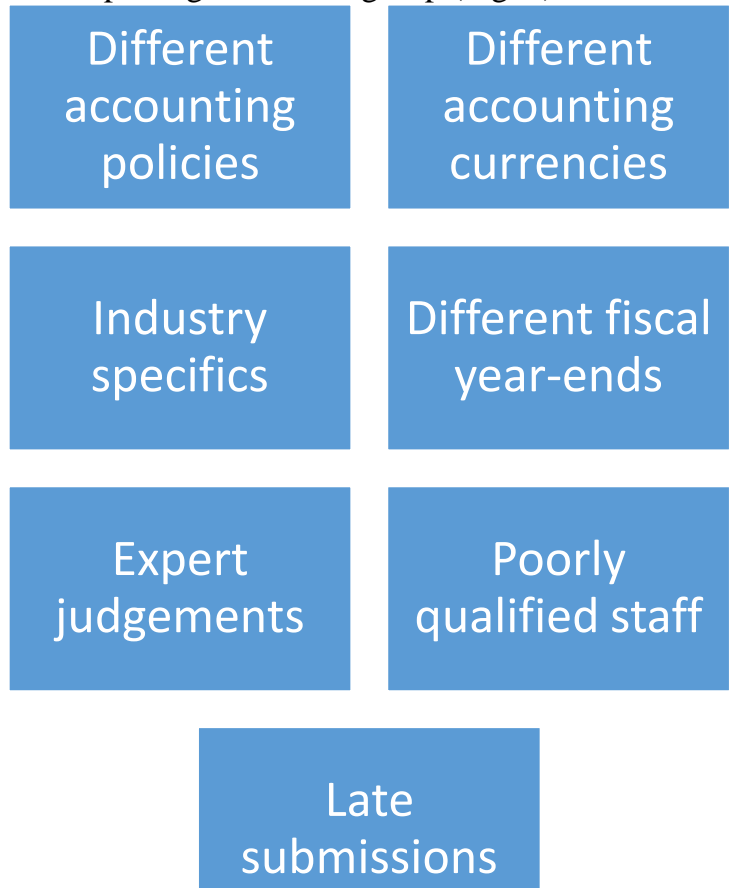

Fig. 3. Automated consolidation challenges related to separate financial reporting

Different accounting policies adopted by the group companies hinder the automated consolidation of separate financial statements since additional adjustments need to be made to bring the parent's accounting policies into line with the subsidiary's accounting policies.

Different accounting currencies result in technical difficulties due to the need to translate the reported values and identify additional translation differences [6].

Industry specifics may require additional items to be introduced in the financial statement to make it more transparent [11].

Different fiscal year-ends require submission of interim financial statements by the subsidiaries so that their statements and the parent's statement have the same reporting date [12].

Expert judgements instead of specific values impair the accuracy and reliability of financial statements [13].

Poorly qualified staff may result in financial reporting being inaccurate due to many errors [16].

Lack of details prevents from obtaining a detailed reporting on certain items [17].

Late submission of data delays the preparation of statements so that they cannot be relied upon when making managerial decisions [19].

There are easy ways to solve such consolidation challenges, all of which are based on the historical cost method:

- Harmonize the accounting policies and chart of accounts in accordance with national standards;
- Develop a uniform accounting policy and chart of accounts in accordance with IFRS standards;

- Develop an IFRS-based procedure for the preparation of separate financial statements with due account of industry specifics;

- Harmonize and develop reporting forms;

- Ensure that all entities use the same financial reporting software;

- Obtain all information about the current and future activities of the group companies;

- Conduct advanced IFRS training for employees. Consolidation issues

Consolidation of financial statements includes the preparation of separate financial statements in accordance with IFRS Standards, as well as a number of process operations, such as elimination (deletion, exclusion) of intragroup transactions, calculation of goodwill and calculation of non-controlling interest.

Preparation of separate financial statements in accordance with IFRS Standards. This operation must be based on the uniform accounting principles and uniform accounting policy issued by the parent. According to IFRS Standards, subsidiaries are not required to provide full financial statements, the main requirement is that the reported values are obtained according to the parent's uniform accounting policy based on IFRS Standards. To this end, the parent may issue special forms for the consolidation of financial statements, to be filled out by the group companies.

Elimination of intragroup transactions. Intragroup transactions, i.e. transactions between members of the group, are nor reported in the consolidated financial statements. Any unrealized profit, i.e. profit that is reported in a separate financial statement, resulting from trading goods, work, services, fixed assets between the group companies (i.e. parent and subsidiary) or between investor and investee, investor and an associated company, investor and a joint venture, must be excluded. Any intragroup profits attributable to the parent (investor) must be eliminated from the consolidated financial statements.

Goodwill calculation. Upon acquisition of a company, its intangible assets, i.e. goodwill, must be identified. Goodwill is calculated by subtracting the fair value of the purchaser's share in the net assets of the purchased company from the total purchase price. In essence, goodwill represents the company's estimated additional economic strength, due to which the company may obtain additional economic benefits in addition to "ordinary" profit from the use of its net tangible assets. There is a number of factors that contribute to the creation of the company's goodwill, i.e. effective marketing campaigns, highly qualified management team, advanced work management, effective employee engagement, loyal customers, implementation of information systems, e.g. ERP, etc. In mergers and acquisitions, goodwill generally represents all intangible income-bearing assets that are not subject to accounting according to the accounting standards.

Calculation of non-controlling interest. This operation is explained by the requirement to report a portion of the consolidated net assets and financial results, which is not attributed to the parent.

\section{CONCLUSION}




\section{Consolidated Reporting Technology: Objectives and Means of Achieving}

In conclusion, it should be noted that group managers choosing to implement automated consolidation of financial statements in accordance with IFRS Standards may face certain process-related and methodological challenges. Such challenges may be caused by such factors, as a poor qualification of financial functions, judgments regarding the availability of control over the group companies, as well as judgments regarding the consolidation method, technical difficulties in calculating goodwill and non-controlling interest. To solve these issues, IT specialists, as well as experts from consulting or audit firms must be involved from the very beginning since the company employees may lack the necessary experience in financial consolidation. Later on, the company employees will acquire adequate experience, complete IFRS training and will be able to prepare consolidated financial statements on their own.

\section{REFERENCES}

1. Kevorkova, Z.A., Petrov, A.M., Savina N.V. Towards liabilities of corporate systems. International Journal of Civil Engineering and Technology. Volume 10, Issue 2, February 2019, Pages 1582-1593

2. Lymar, M.P., Kevorkova, Z.A., Petrov, A.M. The convergence of national and international accounting standards: Chinese experience. International Journal of Civil Engineering and Technology. Volume 9, Issue 13, December 2018, Pages 82-94

3. Karpova T.P., Petrov A.M., Antonova O.V., Directions of Accounting Development in the Conditions of Digitalization. Jour of Adv Research in Dynamical \& Control Systems, Vol. 10, 07-Special Issue, 2018, pp. (117-125)

4. Chernysheva Natalia A., Perskaya Victoria V., Petrov Alexander M., Bakulina Anna A. Green Energy for Belt and Road Initiative: Economic Aspects Today and in the Future / International Journal of Energy Economics and Policy. 2019, 9(5), 178-185

5. Petrov A.M., Nikiforova E.V., Kiseleva N.P., Grishkina S.N., Lihtarova O.V., Creation of the reporting on sustainable development of companies based on socioeconomic measurement statistics / International Journal of Recent Technology and Engineering. Volume-8 Issue-2, July 2019, p. 4005-4012

6. Alexander M. Petrov, Marina V. Kosolapova, Igor G. Yshanov, Nataliya K. Muravitskaya, Hursheda Nurmuhamedova The Economic Significance of Statistical Research Activities of Representative Offices of Companies Abroad / International Journal of Innovative Technology and Exploring Engineering(TM). Volume-8 Issue-10, August 2019 p. 2713-2722

7. Lyudmila V. Sotnikova, Svetlana N. Polenova, Nataliya A. Mislavskaya, Alexander M. Petrov, Mariya M. Basova. Sustainable development, macro and micro level: Russian and foreign model / International Journal of Recent Technology and Engineering. Volume-8 Issue-2, July 2019, p. 4524-4532

8. Nikiforova E.V. PARADIGM OF PUBLIC REPORTING OF ECONOMIC ENTITIES // World Applied Sciences Journal. 2014. T. 29. № 5. C. 667-670.

9. Akhmadeev, R.G., Bykanova, O.A., Turishcheva, T.B. (2018) Brics' foreign debt burden and its impact on core institutional basis. Journal of Reviews on Global Economics, 7, pp. 345-359.

10. Akhmadeev, R.G., Kosov, M.E., Bykanova, O.A., Turishcheva, T.B. (2018) Development of venture financing to ensure economic security of a country. Proceedings of the 32nd International Business Information Management Association Conference, IBIMA 2018 Vision 2020: Sustainable Economic Development and Application of Innovation Management from Regional expansion to Global Growth, pp. 51-56.

11. Akhmadeev, R.G., Bykanova, O.A., Philippova, N.V., Vashchekina, I.V., Turishcheva, T.B. (2018) Macroeconomic indicators and their impact on the foreign debt burden: The case of BRICS countries. International Journal of Economics and Business Administration, 6 (2), pp. 68-82.

12. Akhmadeev, R.G., Bykanova, O.A., Morozova, T.V., Safonova, E.G., Turishcheva, T.B., Lehoux, L. (2018) Evaluation of financial and analytical activities of the biggest car makers of the Russian federation. Jurnal Pengurusan, 54, pp. $131-142$

13. Akhmadeev, R.G., Kosov, M.E., Bykanova, O.A., Korotkova, E.M., Mamrukova, O.I. (2016) Assessment of the tax base of the consolidated group of taxpayers in Russia using the method of polynomial interpolation. Indian Journal of Science and Technology, 9 (12), p. 89533

14. Petrov, A. Modern Accounting Concepts: Textbook. M.: Vuzovsky Uchebnik: INFRA-M, 2018

15. Magomedov R.M., Israpilov K.A., Zolotaryuk A.V., Doguchaeva S.M., Gorodetskaia O.Y., Tsvetkova O.N. Regional taxable capacity measurement methodology based on factors that determine tax gaps based on the example of the Republic of Dagestan // Regional Statistics, Vol. 9. No. 2. 2019: 173-189; DOI: 10.15196/RS090207

16. Suleymanov M.M., Magomedov R.M., Savina S.V., Fomicheva T.L. Basic models of tax federalism in global practice: specific characteristics and structural and functional organization /// Academy of Accounting and Financial Studies Journal, Vol. 22 No. 3. 2018: $1-9$.

17. Magomedov R.M. Digital Technologies for Competitive Analysis and Evaluation of Competitive Capacity of a Business Entity /// International Journal of Innovative Technology and Exploring Engineering (IJITEE). Vol. 9. No. 1. 2019: 1184-1189; DOI: 10.35940/A4522.119119

18. Marina V. Kosolapova, Nataliya K. Muravitskaya, Mihail N. Tolmachev, Lyubov A. Melnikova, Alexander M. Petrov Technology for solving the problems related to the implementation of the concept of preserving capital in accounting and statistics / International Journal of Recent Technology and Engineering. Volume-8 Issue-3, July 2019, p. 789-792

19. A.M. Petrov, N.P. Kiseleva, Z.A. Kevorkova, L.A. Melnikova, I.G. Yshanov Present development practices for tax, financial and statistical reporting in the Russian Federation / International Journal of Innovative Technology and Exploring Engineering(TM). Volume-8 Issue-12, October 2019

20. A.M. Petrov, Y.E. Putihin, M.V. Poluleh, I.O. Yurasova, V.N Erohina. Accountant Modeling Technology and Statistics in the Context of the New Educational Concept / International Journal of Innovative Technology and Exploring Engineering(TM). Volume-8 Issue-12, October 2019.

\section{AUTHORS PROFILE}

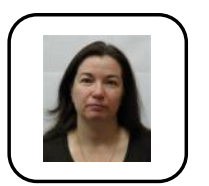

N.D. Brovkina, Ph.D. (Economics), Associate Professor, Department of Accounting, Analysis, and Audit of the Financial University under the Government of the Russian Federation, Moscow, Russia

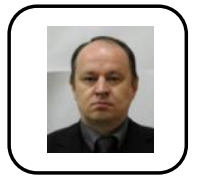

E.V. Negashev- Associate Professor of the Accounting, Analysis and Audit Department of the Financial University under the Government of the Russian Federation (Moscow), PHD. He is the author of more than 60 scientific publications like monographs, textbooks, articles created both personally and in collaboration in the last 14 years.

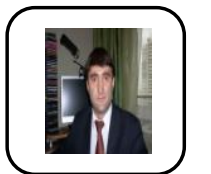

R.M. Magomedov - associate professor of the Department of Data Analysis, Decision-making and Financial Technology, Financial University under the Government of the Russian Federation, Moscow, Russia E-mail: rmagomedov@fa.ru 